\title{
A Pós Graduação no Instituto do Coração da Faculdade de Medicina da Universidade de São Paulo
}

\author{
Charles Mady, Neusa Rodrigues Dini, José Antônio Franchini Ramires \\ São Paulo, SP
}

Um dos grandes avanços na melhoria da qualidade dos docentes das variadas academias e de profissionais em muitas áreas de atuação foi a valorização da pós graduação, estimulada pelo Governo Federal.

Pós-graduação de qualidade, tanto senso lato como senso estrito, é sinônimo de ensino e pesquisa de elevado nível. Ou seja, um dos alicerces mais importantes de uma estrutura acadêmica produtiva é a pós-graduação, sustentando os dois extremos universitários - a graduação e a produção de ciência. A graduação se beneficia muito com a manutenção da qualidade dos seus docentes e a produção científica evolui com o amadurecimento das variadas linhas de pesquisa, de responsabilidade desses mesmos docentes.

Um grande problema enfrentado pela CAPES (Coordenação e Aperfeiçoamento de Pessoal de Nível Superior) foi o estabelecimento de regras que pudessem ser absorvidas pelos centros de ensino e pesquisa deste país, pois a heterogeneidade dos referidos centros é enorme, com conseqüente dificuldade em se criar parâmetros mínimos necessários para análise de qualidade. Todos os centros universitários tiveram dificuldades na adaptação aos novos regulamentos, mas essas dificuldades geraram evolução tanto internamente, com exigências saudáveis perante o corpo docente e os alunos, como externamente, com a busca de intercâmbios com outras academias.

É nossa intenção informar o que tem sido feito em nosso meio, já que o nível de desinformação é enorme, tanto perante 0 público leigo, como perante os profissionais de nossa área.

Em 1975, iniciou-se a primeira turma de pós-graduação senso estrito (mestrado e doutorado) e, na ocasião, contemplavam-se fundamentalmente, médicos da casa. Havia o nítido interesse em formar um corpo clínico graduado, pronto para exercer suas atividades didáticas, científicas e assistenciais no mais elevado nível. Naquele momento, entendeu-se que o nível acadêmico seria item básico para melhoria da qualidade. Dever-se-ia, portanto, qualificar formadores de opinião, educadores em todos os sentidos. No início eram poucos alunos, mas com a ampliação do InCor, os recursos humanos cresceram muito, fazendo com que muitas vagas da pós-graduação fossem ocupadas por médicos da Instituição. Com o tempo, a situação se inverteu e passamos a contar com muitos alunos provenientes de outros serviços. É o que foi chamado de abertura da pós-graduação, o que gerou muitos benefícios e alguns

Instituto do Coração do Hospital das Clínicas - FMUSP

Correspondência: Charles Mady - InCor - Av. Dr. Enéas de Carvalho

Aguiar, 44 - Cep 05403-000 - São Paulo, SP

E-mail: charles.mady@incor.usp.br

Recebido para publicação em 17/10/03

Aceito em 24/3/04 malefícios. O maior dos benefícios foi a oportunidade dada a colegas de outros centros de se graduarem e levar suas experiências e títulos às suas universidades de origem. Ou seja, estava-se qualificando formadores de opinião, acadêmicos, para dar inicio ou enriquecer suas escolas de origem. Estávamos, portanto, "exportando" idéias e conhecimentos, dando início à formação de novos núcleos de excelência.

No caso desses centros serem ainda embrionários, optou-se por uma política de desenvolver cursos e assessorias em conjunto, conforme aprovado pelo Ministério da Educação. Como exemplo, citamos a nossa experiência com a Universidade Federal Fluminense (UFF), com a qual realizamos encontros científicos anuais que valem créditos para os alunos daquela instituição. 0 encontro dura três dias e conta com os corpos docentes de ambas as universidades, sendo que alguns professores da UFF foram, aqui, pós-graduados. Estamos em contato com outras universidades para desenvolver o mesmo programa. Estimula-se, também, o intercâmbio científico, mantendo-se protocolos de pesquisa em conjunto. Como conseqüência, as virtudes de alguns preenchem as deficiências de outros, gerando benefícios para todos.

Como qualquer abertura, houve conseqüente queda de qualidade e aumento no número de alunos que não completavam o curso. 0 nosso trabalho, na ocasião, se concentrou na solução desse problema, baseando-nos nos critérios da CAPES, com muito bons resultados. Tinha-se uma massa crítica de orientadores de alto padrão, mas nem todos com experiência para orientar esse número elevado de candidatos. Aumentou-se o número de orientadores e, obviamente, houve problemas nesse processo. Decidiu-se repensar, com a experiência adquirida, o clássico curso de pós-graduação, estabelecendo-se novos parâmetros a serem seguidos.

Como pré-requisito de aceitação, os alunos devem ter ligações universitárias. 0 aluno deverá desenvolver trabalho dentro da linha de pesquisa de seu orientador e freqüentar sua unidade ou serviço em tempo integral, participando ativamente como membro desse grupo, tanto nas pesquisas como na assistência. Esse tempo de permanência permite vivência com os vários integrantes e métodos do grupo e da instituição, trazendo grande amadurecimento, sendo uma das partes mais importantes na formação dos futuros doutores. Nesse período aprendem ou aperfeiçoam o sentido de academia, de ser parte integrante de uma estrutura cientifica, de aprender para produzir em grupo e ensinar. Muitas vezes valoriza-se a tese em si apenas, que em verdade é o simples coroamento de um processo bem mais complexo. Não se trata apenas de uma publicação científica, mas sim da formação de um futuro professor. Daí a necessidade de sua permanência em tempo integral, em contato diário com seus pares e seu orientador.

Estando a pesquisa concluída, o trabalho será construído e 
apresentado à uma banca de qualificação, constituída por três indivíduos graduados e que tenham linhas de pesquisa semelhantes. A presença do orientador nessa sessão é obrigatória, pois as críticas referem-se a ele também. E sendo aprovado, um ou dois julgadores estarão presentes como membros efetivos da banca final para comentar as mudanças sugeridas na qualificação. Nesta ocasião, o candidato deverá apresentar documento comprovando o envio do texto para uma revista indexada. Isto porque, no início, foi grande o número de teses não publicadas. 0 autor do trabalho deverá ser 0 aluno. 0 orientador só poderá ser o primeiro autor caso o aluno desista de sê-lo, por escrito, ou por desleixo, não escreva o trabalho no período estabelecido.

É obrigação do orientador se fazer presente em todas as etapas evolutivas do aluno. Não se pode aceitar a idéia antiga de que o aluno deve ser um autodidata. Ele vem para aprender e produzir, e orientá-lo é obrigação do orientador. Estará sendo aberta uma página no currículo pós-graduação Lattes para cada orientador, que deverá fazer, periodicamente, relatórios à Coordenadoria da Pós-Graduação. Esta fará, em futuro próximo, análise do desempenho de cada qual, no sentido de despertar em todos a responsabilidade sobre seus alunos, com participação ativa e presença constante ao lado dos candidatos. 0 preenchimento desses quesitos será fundamental na manutenção do corpo de orientadores que é, logicamente, a entidade que dá qualidade ao curso.

Este corpo deverá ser reciclado conforme o desempenho de cada qual, abrindo-se espaço para novos orientadores. 0 número de vagas será por enquanto determinado pela Coordenadoria, mas deveremos atingir um grau de maturidade a ponto de cada orien- tador definir quantos alunos poderá ter, de acordo com suas possibilidades. Não se deve esquecer que a desistência ou não conclusão do curso é ônus negativo para o professor. A pós-graduação é aberta, mas a responsabilidade do orientador é item fundamental.

Todos os alunos deverão passar por um período de experiência nas unidades ou serviços escolhidos, construindo um projeto de pesquisa e submetendo-o à aprovação das Comissões Científica e de Ética. Devem dar início ao projeto e, apenas após este estar viabilizado, o aluno poderá se inscrever no curso, cuja finalidade é minimizar as taxas de insucesso e desistência.

Até recentemente, a pós-graduação era realizada apenas na área médica. No entanto, serviços com recursos humanos de alta qualidade, como enfermagem, psicologia, fisioterapia, nutrição e tantos outros eram obrigados a procurar seus cursos em outros setores. Atualmente, a pós-graduação se realiza em ciências (área de cardiologia) abrindo, assim, oportunidade a todos indivíduos qualificados de pleitear o título acadêmico. Seguramente, a qualidade dos grupos multiprofissionais aumentará e a produção cientifica se multiplicará. Pretende-se formar vários doutores por serviço, para que esses centros sejam referência para pós-graduação e recebam, em futuro próximo, candidatos de outras universidades, repetindo assim o ocorrido na área médica. Dessa forma, o InCor tornar-se-á como um todo, uma academia multiprofissional formadora de professores e pesquisadores em todos os setores ligados à área de cardiologia.

Acreditamos que, com essas mudanças, possamos gerar evolução na qualidade de ensino, pesquisa e atendimento em nossa casa, e possamos auxiliar outros centros a cursar o mesmo caminho. 